\title{
一般演题 16
}

\section{冷凍血液専用超低温槽の試作}

\section{目的}

従来演者らが使用してきた冷凍血液保存用の 冷凍庫は米国製のものであった. しかし，湿度 の低い米国の気候条件にもとづいて設計された 冷凍庫を湿度の高い日本で使用するためには常 に幾つかの久点に悩まされねばならなかった。

したがって, 本研究の目的は高温多湿の日本 で血液を冷凍保存するための専用超低温槽を完 成することにある。

\section{外国业品の欠点}

その 1 つは日本が多湿ゆえに超低温槽の入口 部で凍結した霜や氷が槽内に落下して, 槽の底 が次第に浅くなってくることであった．冷凍血 液は通常 $3 \times 15 \times 20 \mathrm{~cm}$ 程度の紙箱に血液を入 れたプラスチックバッグを折りたたんで容れ， この箱を槽内に整頓して格納するのであるか $ら$, 槽の底部や箱の間隙に多量の霜や氷が重積 したのでは困ってしまう，といって，頻回に槽 内を空っぽにして頻回に霜, 雪, 水などの掃除 はできるものではない，主として米国製の冷凍 庫になぜこのような久点があるかといえば，米 国の湿度は 5 10\% と極度に低い所さえあり， 常に50\%以上あるいは梅雨時には80〜90\%にす ら上昇する多湿の日本の気象条件を想像するこ とは全く不可能であるからである. 米国ではそ の必要性が無いので, 超低温槽運行中に発生す る霜に対する配慮は不必要なためである.こう いったところに，日本の冷凍血液の普及が妨げ られている原因の一つがある.こういった点へ

*1 国立福岡中央病院外科

$* 2$ 萑原設備工業俐
隅 田幸男*1 松原義 範*2
の注意をいま㬇起しておかなければ，多くの施 設に不便な冷凍庫が搬入されてしまってからで は時宜を逸する，小さな工夫で，この霜と氷が 槽内に落下しないような構造の冷凍庫を開発す る必要がある。

その 2 は，冷凍庫内に無神経に突出した温度 計によって公表された内容積よりははるかに小 さな容量しか使用されなかったり，乙かも冷凍 血液の出し入れにも不自由さを生じていること であった.ここにも，工夫が要求される.

その 3 は，高価であることであった．したが って本邦製品ならば 2 台購入できるはずである のに，不便な米国製の泠凍庫ではたった 1 台し か購入できないことである. 本邦で信頼しうる 製品が完成すれば輸入の必要はないし，国情を 考えれば輸入は最少限度に抑えるべきである.

\section{新しい冷凍店のデザイン}

以上のような理由から，演者なは過去 7 力年 間日本で泠涷血液輸血を行ない，約 3,000 本の

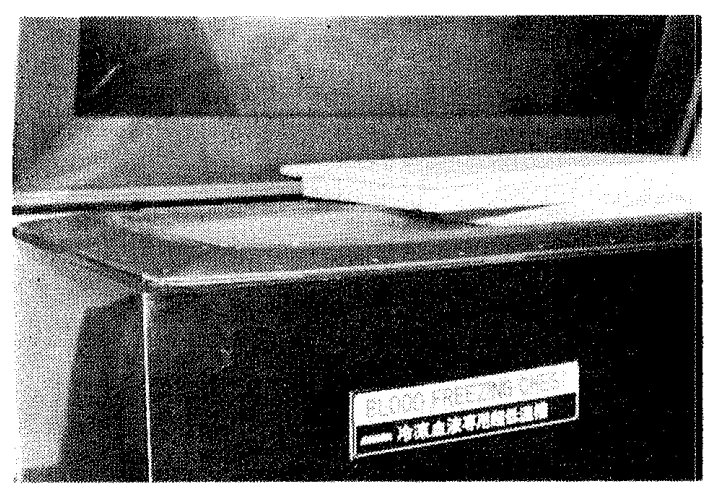

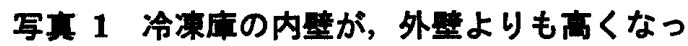
ている点に注意. したがって, 䄪 5 分 間，毫を開けておくと，入口部周辺の 柴と永は融解して外に落下し，䅦内人 は落下しない. また, 内面には温度㖕 の尖端を含めて凸出物は何一つない。 
$(44)$

表 1

\begin{tabular}{|c|c|c|c|c|c|c|c|}
\hline モデル & 内 容 積 & 度 & & $\mathrm{W}(\mathrm{m} / \mathrm{m})$ & $\mathrm{D}(\mathrm{m} / \mathrm{m})$ & $\mathrm{H}(\mathrm{m} / \mathrm{m})$ & 電 \\
\hline \multirow{2}{*}{ B F 200} & \multirow{2}{*}{$250 \ell$} & \multirow{2}{*}{$\begin{array}{c}-90^{\circ} \mathrm{C} \\
\text { (到達温度) }\end{array}$} & 外 寸 & 1,560 & 740 & 1,170 & \multirow{2}{*}{$100 \mathrm{~V} 5 \% 0 \mathrm{~Hz}$} \\
\hline & & & 内 寸 & 760 & 440 & 750 & \\
\hline \multirow{2}{*}{ B F 300} & \multirow{2}{*}{$363 \ell$} & \multirow{2}{*}{$\begin{array}{c}-90^{\circ} \mathrm{C} \\
\text { （到達温度） }\end{array}$} & 外 寸 & 1,900 & 740 & 1,170 & \multirow{2}{*}{$100 \mathrm{~V} 5 \%{ }_{0} \mathrm{H}_{2}$} \\
\hline & & & 内 寸 & 1,100 & 440 & 750 & \\
\hline
\end{tabular}

附 属 品：1週間用自動温度記録計 (U.E 社) インク記録紙付

: アラーム（撆報装置一式）自動充電方式

別途附属品：アルミケース・BF-200 用 12 ケース84組/BF-300 用 18ケース 126 組

血液を冷凍保存し， 400 人余の輸血を必要とす る患者に使用した経験にもとづいて次のような 超低温槽を試作した（表 1, 写真 1).

\section{成 嚗}

上記のモデル BF 300 型 $(363 \ell)$ を過去 6 カ 月間使用した結果, 次のような成績が得られ た. 冷凍赤血球は Huggins 法を改良した隅田

表 2 冷湅血液（赤血球）の臨床応用

\begin{tabular}{|c|c|c|}
\hline & 患 者 数 & 使用本数 \\
\hline 血液不足 & $191(52.9 \%)$ & 1,400 \\
\hline 緊急輸血 & $58(16.1 \%)$ & 277 \\
\hline 単純性貧血 & $67(18.6 \%)$ & 422 \\
\hline 肝 不 全 & $16(4.4 \%)$ & 163 \\
\hline 腎 不 全 & $17(4.7 \%)$ & 216 \\
\hline 輸血反応 & $3(0.8 \%)$ & 8 \\
\hline 計 & $361(100 \%)$ & $2,714(100 \%)$ \\
\hline & \multicolumn{2}{|c|}{$\begin{array}{l}\text { 1969年 } 1 \text { 月 1972年 } 2 \text { 月 } 29 \text { 日 } \\
\text { 国立福岡中央病院 }\end{array}$} \\
\hline
\end{tabular}

の標準化された冷凍赤血球輸血法によるもので あり，冷凍血小板は隅田の原法によって処理し たものである. 赤血球および血小板ともに冷凍 期間中に特に超低温保持の上で支障を来したこ とはなく，解凍脱グリセリン後に輸血した際に
生じる副作用は全く認められなかった. 6 力月 間の維持低温は $-85 \sim-75^{\circ} \mathrm{C}$ を正確に保持し た. また，この期間中に槽内に降下あるいは落 下した霜あるいは氷は，従来の米国製のものに 比べて極く少量で, 約 $1 / 100$ 量であり, 本研究 の目標を完全に満足させた.

\section{まと め}

本邦で輸血に必要な血液成分を冷凍保存する ためには, 本邦の気象条件に合致した構造の超 低温槽 (deep freezer) を使用しなければ, 血液 の安全な長期管理は困難となる. 著者らは, 超 低温槽の開閉ドア接合部の内外壁の高さを違 え, 内面への突出物を排除するという小さな工 夫によって, 本邦における血液の冷凍保存に役 立つ超低温槽を試作した.

この超低温槽を使用して, 赤血球ならびに血 小板を 6 力月間以上 $-75^{\circ} \mathrm{C} \sim-85^{\circ} \mathrm{C}$ に凍結保 存し，これを解凍して輸血することができるこ とを試験し支障ないことを認めた。

文献

隅田幸男: 冷凍血液輸血, 日本医事新報社, 昭和 47 年 1 月刊.

Sumida, S. : Frozen Blood and Its Clinical Use, in Press, Igaku-shoin, 1972. 
表 3 冷凍血小板血絰数

(Clnical Cases of Frozen Platelets Transfusion)

\begin{tabular}{|c|c|c|c|c|c|c|}
\hline No. & Name & Age $/$ Sex & $\begin{array}{l}\text { Blood } \\
\text { Type }\end{array}$ & Diagnosis & $\begin{array}{c}\text { Frozen Platelets Trans- } \\
\text { fusion Numbers \& Donor's } \\
\text { Hemotype }\end{array}$ & 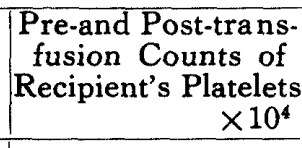 \\
\hline 1 & K.H. & $45 / \hat{\sigma}$ & $\mathrm{O}$ & $\begin{array}{l}\text { l-pulmonary } \\
\text { Cancer }\end{array}$ & 4 , (1) $O \times 4$ & - \\
\hline 2 & T.S. & $55 /$ 令 & B & $\begin{array}{l}\text { r-pulmonary } \\
\text { Cancer }\end{array}$ & $3, \quad(1) \mathrm{B} \times 1, \quad \mathrm{O} \times 2$ & (1) $1.4 \rightarrow 3.8$ \\
\hline 3 & T.o. & $52 /$ 우 & A & Gastric Cancer & 3 , (1) $\mathrm{A} \times 3$ & (1) $1.5 \rightarrow 1.27$ \\
\hline 4 & E.K. & 38/우 & A & ITP & $4, \quad(1) A \times 2, \quad \mathrm{O} \times 2$ & (1) $3.0 \rightarrow 4.2$ \\
\hline 5 & T.S. & 36/우 & A B & ITP & 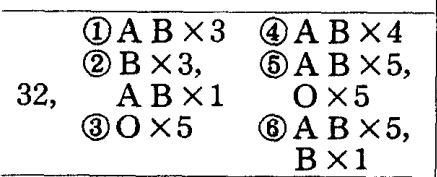 & $\begin{array}{l}\text { (1) } 0.3 \rightarrow 2.4 \\
\text { (2) } 0.8 \rightarrow 5.6 \\
\text { (3) } \sim \text { (6) - }\end{array}$ \\
\hline 6 & R.M. & 28/우 & B & ITP & $\begin{array}{l}9, \quad \text { (1) } \mathrm{B} \times 6 \\
\text { (2) } \mathrm{O} \times 3 \\
\end{array}$ & - \\
\hline 7 & I.H. & $29 /$ 今 & $\mathrm{O}$ & $\begin{array}{l}\text { Klein-Felter } \\
\text { Syndrome }\end{array}$ & 5 , (1) $0 \times 5$ & (1) $1.2 \rightarrow 2.9$ \\
\hline 8 & K.A. & $32 / \hat{8}$ & B & Leucemia & $14, \begin{array}{l}1 \\
\text { (2) } \mathrm{B} \times 6 \\
\end{array}$ & $\begin{array}{l}\text { (1) } 0.8 \rightarrow 1.6 \\
\text { (2) } 1.6 \rightarrow 7.6\end{array}$ \\
\hline 9 & N.K. & $14 /$ 우 & $\mathrm{O}$ & ITP & 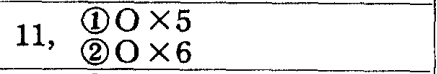 & $\begin{array}{l}\text { (1) } 3.8 \rightarrow 1.3 \\
\text { (2) } 1.3 \rightarrow 2.0\end{array}$ \\
\hline 10 & T.H. & $66 /$ 令 & A & Rectal Cancer & 11 , (1) $\mathrm{A} \times 11$ & (1) $7.8 \rightarrow 18.0$ \\
\hline 11 & M.T. & $21 / \hat{\jmath}$ & A & ITP & 8 , (1) $\mathrm{A} \times 8$ & - \\
\hline 12 & M.N. & 58/우 & A & ITP & $10, \quad$ (1) $\mathrm{A} \times 3, \quad \mathrm{O} \times 7$ & (1) $6.2 \rightarrow 3.7$ \\
\hline 13 & Y.O. & $44 / \hat{8}$ & $\mathrm{O}$ & $\begin{array}{l}\text { Leucemia \& } \\
\text { Splenomegaly }\end{array}$ & 6, & (1) $27.9 \rightarrow 33.5$ \\
\hline 14 & S.Y. & 22/우 & A B & ITP & $10, \quad 1 \mathrm{~A} \mathrm{~B} \times 2, \quad \mathrm{~B} \times 8$ & (1) $0.3 \rightarrow 1.3$ \\
\hline 15 & H.I. & $15 /$ 우 & A & ITP & $12, \quad(1) \mathrm{A} \times 6, \quad \mathrm{O} \times 6$ & (1) $3.7 \rightarrow 2.4$ \\
\hline 16 & K.Y. & $57 / \hat{\sigma}$ & A & ITP & $32, \begin{array}{cc}\text { (1) } \mathrm{O} \times 9, & \mathrm{~A} \times 2 \\
(2 \mathrm{~A} \times 4, & \mathrm{O} \times 7 \\
\text { (3) } \mathrm{B} \times 10 & \\
\end{array}$ & - \\
\hline 17 & K.E. & 47/우 & A & Gastric Cancer & $\begin{array}{lll}\text { (1) } \mathrm{B} \times 2, & \mathrm{~A} \mathrm{~B} \times 1 \\
15, & \mathrm{~A} \times 2, & \mathrm{O} \times 4 \\
\text { (3) } \mathrm{A} \mathrm{B} \times 4, & \mathrm{O} \times 2 \\
\end{array}$ & $\begin{array}{ll}(1) & \\
(2) & 6.6 \rightarrow 12.4 \\
(3) & 12.4 \rightarrow 16.7\end{array}$ \\
\hline 18 & H.T. & 44/우 & $\mathrm{O}$ & Gastric Cancer & $9, \quad(1 \mathrm{~A} \times 6, \quad \mathrm{O} \times 3$ & - \\
\hline 19 & H.H. & $65 / \hat{0}$ & A & $\begin{array}{l}\text { Acute Myeloic } \\
\text { Leucemia }\end{array}$ & $9, \begin{array}{ll}(1) \mathrm{B} \times 2, & \mathrm{AB} \times 2 \\
(2 \mathrm{O} \times 2, & \mathrm{A} \times 1, \quad \mathrm{~B} \times 2\end{array}$ & (1) $1.0 \rightarrow 3.2$ \\
\hline 20 & M.Y. & $18 / \hat{0}$ & $\mathrm{O}$ & $\begin{array}{l}\text { Acute Lympha- } \\
\text { tic Leucemia }\end{array}$ & $18, \begin{array}{l}\text { (1) } \mathrm{B} \times 8 \\
\mathrm{O} \times 10\end{array}$ & $\begin{array}{l}\text { (1) } 0.4 \rightarrow 1.6 \\
(20.8 \rightarrow 0.92\end{array}$ \\
\hline 21 & I.O. & $68 / \hat{\delta}$ & 0 & $\begin{array}{l}\text { Esophogeal } \\
\text { Cancer }\end{array}$ & $6, \quad(1) 0 \times 6$ & - \\
\hline 22 & T.I. & $62 / \hat{\delta}$ & A & Gastric Cancer & $\begin{array}{l}\text { (1) A } \times 10 \\
23, \text { (2) } \times 9 \\
\text { (3) } \mathrm{A} \times 4 \\
\end{array}$ & - \\
\hline
\end{tabular}

Total 254 units

Keys : (1) means the first transfusion, $B \times 4$ means 4 units of frozen platelets of hemotype $B$ donors, $D$ means Days, $M$ Month, $\times$ unit number. 